\title{
Eksegese en prediking: Romeine 7:14-25 as toetsgeval
}

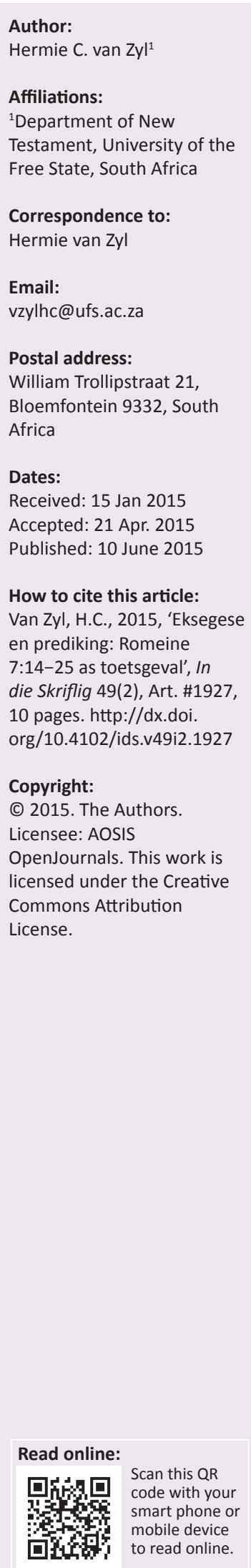

Eksegese is nie 'n eksakte wetenskap nie. Dikwels is meer as een geldige lesing van die teks moontlik. Dit bring mee dat predikers dikwels keuses tussen eksegetiese opsies moet uitoefen. Romeine 7:14-25 is so 'n geval. Dit word allerweë erken as 'n crux interpretum. Die eksegetiese opsies wissel oor die identiteit van die 'ek' in hierdie perikoop, asook oor die stadium in die 'ek' se lewe - vóór of ná sy bekering. Hierdie artikel beredeneer die eksegetiese opsie dat Paulus hier oor sy lewe praat vóór hy 'n volgeling van Christus geword het. Vervolgens word aangetoon watter implikasies dit vir die prediking het.

Exegesis and preaching: Romans 7:14-25 as test case. Exegesis is not an exact science. Often, more than one valid reading of the text is possible. This results in preachers often having to choose between exegetical options. Romans 7:14-25 is a case in point. It is widely recognised as a crux interpretum. The exegetical options vary on the identity of the ' $I$ ' in this pericope as well as on the stage in the life of the ' $\mathrm{I}$ ' - whether before or after his conversion. This article argues the exegetical option that Paul is speaking here about his life before he became a follower of Christ. Subsequently the implications this choice holds for preaching on this pericope is discussed.

\section{Inleiding}

Eksegese is nie 'n eksakte wetenskap nie. Daar is meermale meer as een geldige lesing van die teks moontlik. Eksegete het geleer om met hierdie meerduidighede van die teks saam te leef. Beter gestel: Die verskillende moontlikhede van die teks het juis tot gevolg dat eksegese 'n opwindende wetenskap is wat die eksegeet uitnooi om die rykdom van die teks te ontgin. Die prediker kan egter selde bekostig om vryblywend tussen eksegetiese moontlikhede te skipper. Die eise wat die prediking stel, vereis dat keuses gemaak moet word - keuses wat nie altyd maklik is nie.

Hierdie dilemma word seker nêrens beter as in Romeine 7:14-251 geilllustreer nie. Hierdie perikoop kan met reg 'n crux interpretum genoem word. ${ }^{2}$ Die twee groot eksegetiese kwessies hier ter sprake,

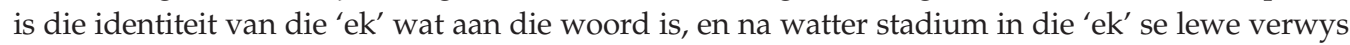
word. Veral oor laasgenoemde kwessie is eksegete steeds in ten minste twee kampe verdeel: diegene wat sê dat dit gaan oor die 'ek' se vóór-Christelike bestaan, en dié wat daarvan oortuig is dat juis sy Christelike bestaan beskryf word. Dat hierdie keuse nie 'n ligtelike kwessie is nie, word verwoord deur Garlington (1990:197) wat beweer dat 'n mens se verstaan van Romeine 7 in 'n groot mate bepalend is vir jou siening van Paulus se hele teologie. Garlington se stelling is debatteerbaar, maar wat nie weggeredeneer kan word nie, is dat Romeine 7 die prediker voor moeilike keuses stel. Dit is ook onteenseglik waar dat die eksegetiese keuse wat uitgeoefen word, die prediker noodwendig in 'n bepaalde rigting stuur, veral wanneer daar erns van die eksegese van die teks gemaak word.

Gevolglik is dit die oogmerk van hierdie bydrae om 'n bepaalde eksegetiese keuse aangaande Romeine 7 te beredeneer en aan te toon hoe dit die prediking beïnvloed. Eerstens word die vraag, naamlik wie die 'ek' van Romeine 7 is, aan die orde gestel; ${ }^{3}$ vervolgens, watter stadium in die lewe van die 'ek' ter sprake is; en laastens, watter invloed die keuses, gemaak tussen die eerste twee kwessies op die prediking uit 7:14-25 uitoefen. ${ }^{4}$
2.Schröter (2013:198) toon aan hoe hierdie mening deur baie geleerdes gedeel word.

3.Die fokus is veral op 7:14-25 (om redes wat later sal blyk), maar die 'ek' is reeds vanaf 7:7 aan die woord.

4.Die afbakening van hierdie perikoop as as 7:14-25 is nie sonder debat nie, aangesien sommige eksegete dit as vanaf verse 13-25 neem (bv. Jewett 2007:458-459; Wilckens 1980:83-85). Gewoonlik is dit egter die tydswisseling van die werkwoorde wat die deurslag gee dat die afbakening verse 7-13 en 14-25 is. In eersgenoemde perikoop is die werkwoorde hoofsaaklik in die verlede tyd en in laasgenoemde in die teenwoordige tyd. Baie eksegete neem dit as afbakeningskriterium (bv. Lohse 2003:219; Schlier 1979:228; Witherington in die teenwoordige tyd. Baie eksegete neem dit as afbakeningskriterium (bv. Lohse 2003:219; Schlier 1979:228; Witherington
2004:186-187). Lohse se beskouing is dat daar in verse 7-13 beskryf word hoe die dodelike alliansie tussen sonde en wet in die verlede 2004:186-187). Lohse se beskouing is dat daar in verse 7-13 beskryf word hoe die dodelike alliansie tussen sonde en wet in die verlede
tot stand gekom het, terwyl $14-25$ aantoon hoe hierdie dodelike verbinding in die praktyk in die hede uitwerk. Selfs by eksegete wat die afbakening as verse 13-25 neem (Wilckens 1980:83-85), of wat 7-25 as 'n eenheid neem (Dunn 1988:376-377), is daar die erkenning dat vers 13 'n skarnierfunksie tussen die twee perikope vervul (vgl. ook Moo 1996:424). In my hantering van Paulus se argument in Romeine 7 , sluit ek by die navorsers aan wat die indeling as verse 7-13 en 14-25 neem. 


\section{Wie is die 'ek' van Romeine 7:14-25?}

Alvorens daar voortgegaan word om die kwessie van die 'ek' se identiteit in 7:14-25 te beredeneer, moet dit genoem word dat hierdie vraagstelling, asook dié oor watter stadium in die ' $\mathrm{ek}^{\prime}$ se lewe ter sprake is, ten nouste met mekaar verweef is. Die antwoord op die eerste kwessie beïnvloed die antwoord op die tweede en andersom. Mens kan dus nie regtig die twee sake van mekaar skei nie. Ter wille van die sistematiese aanpak van die probleem sal die twee afsonderlik hanteer word.

Verder, oorhoofs tot die verstaan van die argument in Romeine 7, moet dit voortdurend voor oë gehou word dat hierdie gedeelte oor die posisie van die Mosaiese wet handel (Schreiner 1998:344). ${ }^{5}$ Een van die sentrale argumente van Paulus in die hele Romeinebrief is dat die wet van Moses geen heilsbemiddelende funksie het nie; dit kan nie jou

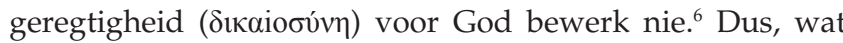
ook al as oplossing vir Romeine 7 aanvaar word, dit moet 'n antwoord bied oor die kwessie van die posisie van die Mosaïese wet in die redding van die mens.

Laastens, dit is weliswaar 'n kwessie van detaileksegese, maar oorhoofs kan gesê word dat waar 'wet' (vó $\mu$ os) en 'gebod' ( $\dot{v} v \tau \circ \lambda \eta)$ in Romeine 7 ter sprake is, die referensie in die algemeen nie soseer die dekaloog is nie, maar die wet van God soos dit binne die Joodse interpretasie daarvan in die tyd van Paulus gefunksioneer het; vó $\mu$ ○ se kontekstuele verwysing in Romeine 7 is dus die wet van Moses (sien ook Fitzmyer 1993:455-456; Goodrich 2013:489; Moo 1996:424, 428), ${ }^{7}$ soos dit algemeen bekend gestaan het.

Vervolgens word die 'ek' van 7:14-25 bespreek. Die basiese vraag hier is: Is die 'ek' outobiografies of nie? Dit wil sê, verwys Paulus hier na homself of na iemand anders? Die volgende opsies is ter sprake:

\section{'Ek' is nie outobiografies nie}

W.G. Kümmel se epogmakende proefskrif in 1929, Römer 7 und die Bekehrung des Paulus (Kümmel 1974)', het 'n

5.Deenick (2010:122) is egter van mening dat die wet nie die sentrale vraagstelling van Romeine 7 is nie, maar wel die stryd tussen die twee aspekte van die 'ek' die een wat God wil dien en die ander wat teen God stry. Veral die slot, 7:21-25, die een wat God wil dien en die ander wat teen God stry. Veral die slot, 7:21-25, waar hierdie stryd (andermaal) verwoord word, bring hom tot hierdie slotsom of status van die wet ontketen word, en dat Paulus daarom die wet in Romeine 7 as fokuspunt neem.

6.Oor wat die presiese oogmerk van Paulus met die Romeinebrief was, is daar geen eenstemmigheid onder geleerdes nie (vgl. McDonald \& Porter 2000:455-459 se oorsig oor die verskillende opsies). Wat ook al die rede(s) vir Paulus se skrywe was, die feit bly staan dat die status van die wet van Moses 'n strategiese rol in die argument van Romeine speel.

7.Nó $\mu$ o se verwysing in Romeine 7 as die 'wet van Moses' geld waar vó $\mu$ o religieus aangewend word. Daar is egter gevalle in Romeine 7 waar vó aangewend word, soos in 7:1-3, 21 (vgl. Newman \& Nida 1973:128, 140). Romeine $7: 23$ is ' $n$ besonder moeilike geval. Die gebruik van vóuoc kan hier waarskynlik $7: 23$ is ' $n$ besonder moellike geval. Die gebruik van die 'wet van sonde' of 'sondige natuur' (vgl. Ridderbos 1959:159; Witherington 2004:202).

8.In 1974 het 'n herdruk van Kümmel se 1929-proefskrif verskyn, in een band opgeneem saam met ' $n$ ander boek van hom, Das Bild des Menschen im Neuen Testament, wat in 1948 verskyn het. waterskeiding in die debat oor die 'ek' van Romeine 7 gebring. Sedert Martin Luther se tyd was die konsensus binne die Protestantse teologie dat Paulus oor sy eie ervaring as Christen (later meer hieroor) praat. Kümmel (1974:111) het egter 'n einde aan hierdie outobiografiese konsensus gebring deur daarop te wys dat só 'n siening nie met Filippense 3:5-6 strook nie. Hier stel Paulus dit duidelik dat hy, vir sover dit die geregtigheid van die wet betref,

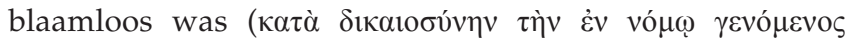
$\ddot{\alpha} \mu \varepsilon \mu \pi \tau$ ) $)$. Paulus het dus 'n positiewe houding teenoor die wet gehad en geen slegte gewete daarop nagehou nie. Volgens Kümmel kan dit nie Paulus wees wat in Romeine 7 , waar die skrywer worstel met die uitvoering van die wet, aan die woord is nie. Daarmee is die outobiografiese siening van die 'ek' in Romeine 7 vir dekades lank op die agtergrond gedruk.

In 1977 het E.P. Sanders verdere gewig aan hierdie standpunt verleen deur 'n meer gematigde siening oor die Judaïsme ${ }^{9}$ van die eerste eeu n.C. voor te hou as wat tradisioneel aanvaar is (die sg. 'new perspective' oor Paulus en die eerste-eeuse Judaïsme). Hiervolgens het die Jode nooit ' $\mathrm{n}$ kru wetsgeregtigheid verkondig nie, maar eerder 'n verbondsgeregtigheid waarbinne die wet 'n positiewe rol vervul het. ${ }^{10}$ Volgens Sanders het die Jode nooit gesê dat die nakoming van die wet as sodanig, geregtigheid voor God bewerk nie. Die genade van God is inderdaad onontbeerlik om die mens binne 'n verbondsverhouding te betrek. Binne hierdie genade- of verbondsverhouding het die wet van Moses dan die belangrike funksie vervul deur konkrete gestalte aan hierdie verhouding te gee. Vandaar die klem op die wet van Moses in die bladsye van die Nuwe Testament wat deur die Protestantse teologie, op voetspoor van Luther, verkeerdelik as 'n wetsgeregtigheid vertolk is.

Ten spyte van kritiek teen Sanders, byvoorbeeld sy onderspeling van die negatiewe invloede van die wetsverstaan onder die Jode, het sy standpunt tog hierdie konsensus tot gevolg gehad dat Nuwe-Testamentici vandag baie versigtiger en meer genuanseerd oor die eerste-eeuse Jodedom se sogenaamde wetsgeregtigheid oordeel.

Paulus se polemiek teen die Jode moet dus van die Jode se situasie self onderskei word. ${ }^{11}$ Die Jode het oor die

\footnotetext{
9.Ek is bewus daarvan dat die Judaïsme van die eerste eeu nie'n monolitiese verskynsel was nie, maar groot interne variasie vertoon het. Die blote verskynsel van die bestaan van verskillende godsdienstige partye soos die Fariseërs, Sadduseërs en bsseners bevestig dit. Hierdie verskille is egter nie van deurslaggewende belang vir
Essen Esseners bevestig dit. Hierdie verskille is egter nie van deurslaggewende belang vir verskille gewys, maar origens word die oorhoofse begrippe Judaïsme, Jodedom of Jode gebruik, soos dit trouens ook in die literatuur voorkom.

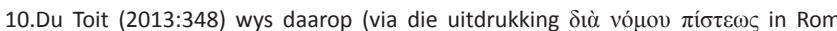
3:27) dat die Torah (hy neem 'wet' hier as verwysing na die Torah) die beoefenaar daarvan implisiet na die geloof lei. Dit is dus ingeskrewe in die wet dat dit deur geloof begelei word. In hierdie sin het die wet dus 'n soteriologiese funksie - dit bring die mens wat onder die vloek van God verkeer tot die erkenning om geheel en al van die genade van Hom afhanklik te wees.

11.Kim (2002:151-152) bevestig egter dat daar wel faksies onder die Jode was, waarvan Paulus moontlik deel was, wat 'n hoër mate van getrouheid aan die wet as die gemiddelde Jood nagejaag het. Wanneer Paulus dus kritiek uitoefen op die Jode dat hulle nie kan doen wat die wet vereis nie, teken hy nie 'n karikatuur van Jode dat hulle nie kan doen wat die wet vereis nie, teken hy nie ' $n$ karikatuur van
die Jode van sy tyd nie, maar kon hy hierdie meer puristiese groepe in die oog gehad het.
} 
algemeen nie die wet, as sodanig, as 'n ondraaglike las of dwingelandy beleef nie. Hier kan aan Psalm 119 gedink word - 'n lang ode oor die digter se liefde vir die wet. Die refrein, 'Hoe lief het ek $u$ wet' loop soos 'n goue draad daardeur. Dit laat mens besef dat die wet van Moses ook vir die eerste-eeuse Jodedom 'n vreugde was. Dit was 'n lewenswyse wat stabiliteit en identiteit aan hulle daaglikse bestaan gegee het. ${ }^{12}$

Wat wel waar was - en dít is wat Paulus in geen onduidelike taal probeer demonstreer het - is dat daar ook 'n neiging onder die Jode was om die wet as 'n uitsluitingsen diskriminerende meganisme te laat funksioneer vanuit die oortuiging dat die wet hulle in ' $n$ bevoorregte posisie by God geplaas het (vgl. Dunn 1998:145, 348). ${ }^{13}$ Almal wat nie by die verbondsverhouding ingesluit was, en gevolglik nie die wet van Moses onderhou het nie, byvoorbeeld die heidene, het per definisie geen deel aan die koninkryk van God gehad nie. Die Jode het gevolglik 'n meerderwaardige houding teenoor nie-Jode ontwikkel. Hierteen was Paulus in verset. Daarom dat hy in 3:23 sê dat almal - heiden én Jood - ewe skuldig voor God staan. Die feit dat jy die wet onderhou, besorg nie aan jou die $\delta$ เк maak jou nie minder skuldig voor die aangesig van God nie. ${ }^{14}$

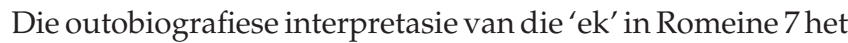
dus na Kümmel se bydraes aan gewildheid ingeboet. Waarna verwys die 'ek' dan? Sedert die vroegste tye is daar ander moontlikhede geopper, maar wat die moderne tyd betref, het geleerdes opnuut begin om die ander moontlikhede te ontgin of met nuwes vorendag te kom. Ek gee kortliks daaraan aandag.

\section{'Ek' verwys na Adam}

Baie van die vroeë kerkvaders, byvoorbeeld Teodoretus (5e eeu n.C.), het gedink dat veral 7:7-12 eintlik net in terme van Adam verstaanbaar is. In moderne tye word hierdie standpunt deur geleerdes soos Käsemann (1980:196-198), Longenecker (1971:92), Dunn (1988:378384), Stuhlmacher (1994:106-107) en Witherington (2004) gehuldig. Witherington (2004:186) parafraseer 7:8-11 só dat dit duidelik blyk dat hierdie verse na Adam se versoeking deur die slang in die paradys verwys:

${ }^{8}$ But the serpent [Sin], seizing an opportunity in the commandment, produced in me all kinds of covetousness ... ${ }^{9}$ But I [Adam] was once alive apart from the Law, but when the

12. Witherington (2004:197) stel dit so: "If we take ... Ps 119 as a sort of transcript for Jewish experience of the Law, Jews delighted in the Law and saw wrestling with the Law and striving to keep its commandments as a joy ...'.

13.Volgens Schreiner (2009:141) is Dunn en Wright (verteenwoordigers van die new perspective op Paulus) se hoofargument dat Paulus nie teen die legalisme van die Jode gepolemiseer het nie, maar teen die feit dat hulle die wet as uitsluitingsmeganisme hanteer het. Schreiner gaan voort om te argumenteer dat, afgesien van Dunn en Wright se standpunt, daar ook spore van legalisme in die Paulus teen die Jode se legalisme gehad het.

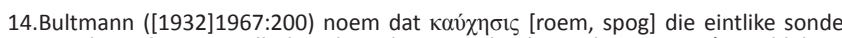
van die Jode was. Hulle het die gehoorsaamheid wat die wet eis, 'n middel tot van die Jode was. Hulle het die gehoorsaamheid wat die wet eis, ' $n$ middel tot
roem en selfverwesenliking gemaak en so verval in die oersonde van die mens om sy eie god te wees. commandment came, Sin sprang to life and I died, ${ }^{10}$ and the very commandment that promised life, proved deadly to me. ${ }^{11}$ For Sin [the serpent] seizing an opportunity through the commandment, deceived me and through it killed me.

Dit is duidelik dat daar waarheid steek in hierdie interpretasie. Veral die gedagtes van 'begeerte' (7:8) en 'verleiding' (v. 11), en dat die 'ek' eers sonder die wet gelewe het (v. 9), maak goeie sin in die paradysverhaal. Die meeste geleerdes aanvaar die paradysverhaal as tradisieagtergrond, maar waarsku terselfdertyd dat dit eerder by wyse van assosiasies as direkte verwysing geskied (vgl. Reichert 2009:305-306). Verder speel Adam 'n belangrike rol in die deel van Romeine vóór hoofstuk 7 wanneer Paulus die ou en die nuwe Adam teenoor mekaar stel (5:12-21). Dit sou dus nie ongemotiveerd voorkom as daar in Romeine 7 ook 'n subtiele verwysing na Adam opduik nie.

Daar is egter gewigtige besware teen die Adam-interpretasie:

- 'n Mens sou verwag dat Paulus, soos in 5:12 en verder, een of ander aanduiding gee dat Adam die verwysing hier is. Daar word egter geen sodanige aanduiding gegee nie. Dit bly dus spekulasie om Adam as verwysing te postuleer (vgl. Schröter 2013:209-210).

- Die interpretasie maak goeie sin in 7:7-12, maar nie in verse 13-25 nie, ten spyte van Longenecker se standpunt dat die basiese argument in 7-25 oor die korporatiewe identifikasie tussen Paulus en Adam handel. Spitsvondig formuleer Longenecker (1971:92) dit soos volg: in 7:7-12 gaan dit oor Paulus in Adam, en in vers 13-25 oor Adam in Paulus. In 7:13-25 handel dit dus oor die voortgaande effek van die verbondenheid tussen Adam en Paulus (Moo 1996:426). Feit is egter dat daar geen dwingende rede is om Adam in die argument van 7:13-25 in te sluit nie.

- Die grootste beswaar is egter dat die wet, naamlik die dominante tema van Romeine 7, nie 'n integrerende argument in die Adam-teologie vorm nie - nie in Genesis nie en ook nie in die Joodse interpretasies rondom Adam nie (Jewett 2007:442). Die stryd van die ' $\mathrm{ek}^{\prime}$ tussen die goeie en die kwade, wat so kragtig in 7:13-25 beskryf word, maak nie sin in Adam se lewe in die paradys nie. Toe het die wet nog nie bestaan om hierdie stryd in Adam te kon ontketen nie. Hierdie stryd pas eerder by die mens wat reeds 'n geskiedenis van in-sonde-gevalle-te-wees het en dan met die wet gekonfronteer word.

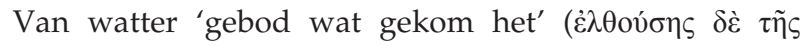
$\dot{\varepsilon} v \tau$ $\tau \tilde{\eta} \varsigma$; 7:9) sou daar in die lewe van Adam sprake gewees het? Die gebod om nie van die boom van die lewe te eet nie? So 'n spesifieke konnotasie is skaars denkbaar in die lig van die totale beredenering rondom 'wet' en 'gebod' in Romeine 7 wat kennelik die Mosaïese wet in die visier het. Daar is wel 'n Joodse siening dat die Torah ewig is en daarom reeds aan Adam gegee is om te onderhou (vgl. Garlington 1990:208; Jewett 2007:451; Schreiner 1998:361), maar Paulus maak nêrens van hierdie tradisie gebruik nie. Trouens, in 5:13 sê hy 
uitdruklik dat die wet nie in Adam se tyd daar was nie (vgl. ook Gal 3:17 waar Paulus byvoeg dat die wet eers 430 jaar na Abraham gekom het). Wat meer is, dit is Paulus se algemene teologiese uitgangspunt dat die wet nie 'n allesbepalende heilsfunksie vervul nie, want die wet is eers lank nadat God sy heilsverbond met Abraham opgerig het, gegee.

Alles in ag genome is dit net te geforseerd om die beredenering rondom die wet in Romeine 7 aan Adam te verbind.

\section{'Ek' is 'eksistensieel'}

Daar is verskillende maniere hoe hierdie voorstel verwoord kan word: die 'ek' is kosmies-histories, verteenwoordig die hele mensdom, of is ' $n$ algemene manier van praat sonder dat dit enige groep of individue in gedagte het (vlg. Moo 1996:426-427). ${ }^{15}$ Die gedagte agter al hierdie formulerings is

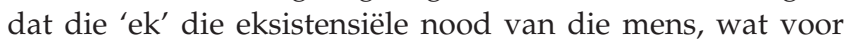
die volmaakte wil van God te staan kom, verteenwoordig, naamlik dat hy ver te kort skiet. Schröter $(2013: 212,220)$ sê byvoorbeeld dat die 'ek' kwalik op Paulus betrekking het omdat die aanduidings te vaag is. Vir hom is die ' $\mathrm{ek}^{\text {' eerder }}$ prinsipieel van aard - verteenwoordigend van elke mens onder die aanspraak van God, maar tegelyk aan die sonde onderworpe.

Hoe waar hierdie voorstel ook al mag wees, is dit te algemeen om van waarde vir die uitleg van Romeine 7 te dien. Daarom word dit daar gelaat.

\section{'Ek' verwys na Israel}

Volgens hierdie interpretasie ${ }^{16}$ sluit die volgorde van gebeure in 7:9-10 aan by wat Paulus op baie ander plekke as Israel se dilemma met die wet voorhou: die koms van die wet het nie Israel se geestelike situasie verbeter nie, maar vererger.

So gesien, verwys 7:9a se 'Ek het eens sonder die wet gelewe' na die tyd in Israel se bestaan vóórdat Moses die wet aan hulle by die berg Sinai gegee het. Toe was hulle, relatief gesproke, geestelik lewend. Ná die wet egter gegee is, het die sonde 'tot lewe gekom', en het Israel gesterwe ${ }^{17}(7: 9 b)$. In die lig van die wet, het dit toe duidelik geword dat hulle lewe nie 'blaamloos' is nie. Die koms van die wet het 'n onbedoelde gevolg gehad: dit het as 't ware die sonde uitgelok, en so het dit duidelik geword dat Israel die wet nie kan nakom nie en eerder dood is $(7: 9 b, 10 b)$.

Volgens hierdie interpretasie word 7:14-25 dan gesien as die voortgaande situasie en stryd van Israel onder die Mosaïese wet. Dit word dikwels ook die heilshistoriese interpretasie genoem vanweë die opeenvolgende geestelike tydperke

15.Marshail (2004:320) is van mening dat dit ' $n$ algemeen menslike eienskap is - ook van ongelowiges - om die goeie te wil doen.

16. Hierdie interpretasie is veral in die vroeë kerk voorgestaan (Lohse 2003:214).

17.'Sterwe' verwys hier waarskynlik na die dood wat altyd die gevolg van sonde is (Rom 6:23; Jewett 2007:452). in Israel se geloofslewe wat so uitgebeeld word (vgl. Moo 1996:426). ${ }^{18}$

Sommige geleerdes soos Moo (1996:431) en Goodrich $(2013: 489,491)$ kombineer die 'ek' wat na Israel verwys met die interpretasie waar ' $\mathrm{ek}^{\prime}$ na Paulus verwys (kyk volgende afdeling met die opskrif ' $E k^{\prime}$ is ' $n$ retoriese stylfiguur). Dit is weens die sterk outobiografiese trekke wat veral in 7:14-25 sigbaar is. Die 'ek' van 7:7-25 word dan gesien as Paulus wat homself as solidêr met Israel beskou. Hoewel Paulus nie al die gebeure wat hier beskryf word persoonlik en bewustelik beleef het nie, beskryf en beleef hy alles as 'n volksgenoot wat persoonlik by Israel se stryd in die uitleef van die wet betrokke is.

Om die noue verband tussen Paulus en Israel te bevestig, toon Goodrich (2013:479, 482-486) uitvoerig aan hoe Paulus in 7:14-25 waarskynlik subtiele intertekstuele toespelings maak op Israel se ballingskap via bepaalde uitdrukkings in Jesaja 49-50. Byvoorbeeld, die uitdrukkings 'om 'n gevangene te wees' en 'verkoop te wees onder die sonde', albei van 7:23, 14, sou onderskeidelik na Jesaja 50:1 kon verwys waar God Israel daarop wys dat hulle, weens hulle sondes, verkoop is in ballingskap; en na Jesaja 49:24-25 waar daar van verlossing uit gevangenskap sprake is. Paulus gebruik dus 'verkoop wees' en 'om 'n gevangene te wees' uit Jesaja 49-50 as intertekstuele metafore om sy eie 'verkoop wees onder die sonde' en 'gevangene te wees van die wet van sonde' (7:14, 23) te beskryf.

Die interpretasie waar die ' $\mathrm{ek}^{\prime}$ na Israel verwys, word op sy beurt deur twee besware beklem:

- Dit is moeilik om goeie parallelle te kry waar 'n groep met die eerste persoon voornaamwoord (enkelvoud) aangedui word, veral waar daar nie 'n duidelike inleidende frase is wat so 'n verband lê nie (vgl. Jewett 2007:442).

- Dit is moeilik om jou die eerste-eeuse Jode voor te stel wat soveel wroeging met die uitleef van die wet van Moses sou ervaar. Hierbo is juis aangetoon dat so 'n siening nie die gemiddelde Jood se ervaring van die wet sou verteenwoordig nie. Hulle was meer positief teenoor die wet ingestel.

Ten spyte van genoemde besware, bied hierdie oplossing, gekombineer met die volgende een, myns insiens die mees aanvaarbare oplossing vir die 'ek' se verwysing in Romeine 7.

\section{'Ek' is ' $\mathrm{n}$ retoriese stylfiguur}

Kümmel (1974:87) het reeds in 1929, toe hy die outobiografiese interpretasie van die 'ek' verwerp het, die voorstel gemaak dat die skrywer hier 'n retoriese stylfiguur gebruik sonder dat enige persoonlike verwysing bedoel word. Hierdeur beweer Kümmel dat die 'ek' van Romeine 7 nie aangewend kan word as 'n biografie van Paulus se bekering nie. Kümmel verwys na soortgelyke voorbeelde by antieke skrywers waar 18.Sien byvoorbeeld Chrysostomos (Lohse 2003:214). 
hulle die 'ek' as stylfiguur aanwend sonder enige persoonlike verwysings na die outeur.

Hoewel hierdie siening van Kümmel 'n nuwe baan van interpretasie vir Romeine 7 geopen het wat gou baie aanhangers gewen het, het al meer geleerdes in die afgelope dekade of twee na vore gekom wat, enersyds, op die leemtes in Kümmel se antieke voorbeelde gewys het (dit vorm nie heeltemal parallelle vir Romeine 7 nie - te kort passasies, en by sommige sluit die 'ek' die outeur in). Andersyds is aangetoon dat dit onmoontlik is om die outobiografiese elemente in die uitgebreide diskoers van Romeine 7 te verwyder. Seifrid (1992:314) wys byvoorbeeld daarop dat Paulus in 7:7 homself baie duidelik by die 'ons' van die retoriese vraag insluit. As Paulus vervolgens met die eerste persoon voortgaan, sien hy homself as tipies of verteenwoordigend van die lesers - die 'ons'.

Die resente terugkeer na Kümmel se oplossing van die 'ek' as retoriese tegniek word vervolgens met 'n outobiografiese verstaan daarvan gekombineer. Dit het gevolg uit die bydraes van Stowers $(1981,1997)$ en andere (vgl. DeSilva 2004:620). Hulle wys daarop dat wat Paulus in Romeine 7 doen, ooreenstem met die wyd-verbreide gebruik onder antieke Griekse skrywers van $\pi \rho \circ \sigma \omega \pi$ oловí $\alpha$ (prosopopoeia). Hiervolgens laat die outeur 'n denkbeeldige karakter namens hom in die eerste persoon praat om so 'n argument te voer wat emosioneel baie meer effektief is as wanneer die outeur self die argument sou voer. Die denkbeeldige karakter word 'n 'toespraak-karakter' ('speech-in-character') genoem (vgl. Jewett 2007:444-445, 471).

Dit wil lyk asof hierdie interpretasie van die ' $\mathrm{ek}^{\prime}$ in Romeine 7 tans wye aanhang onder navorsers geniet en of dit besig is om in 'n nuwe konsensus te ontwikkel (vgl. DeSilva 2004:620). Jewett (2007:441) gaan selfs so ver om te sê dat die vraag na die 'ek' van Romeine 7 met hierdie interpretasie opgelos is. Die 'ek' is naamlik Paulus, via die denkbeeldige karakter. Paulus skep hierdie denkbeeldige karakter wat hy dan aanwend om sy eie siening oor die onvermoë van die wet van Moses te beredeneer. Dis so 'n intens emosionele argument dat outobiografiese elemente daarin verweef is. Daarmee

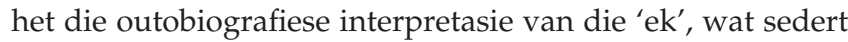
Kümmel se bydraes in onguns verval het, weer volledig teruggekeer. Na my mening kan dit verder gekombineer word met die oplossing waar ' $\mathrm{ek}^{\prime}$ as verwysing na Israel gesien word, soos verduidelik in die vorige afdeling. Dit bied vir my die mees bevredigende interpretasie van die 'ek' in Romeine 7, naamlik Paulus vereenselwig hom volledig as verteenwoordiger van Israel met laasgenoemde se dilemma met die wet. Hy wend ook die 'ek', veral die 'ek' as yweraar vir die wet (sien Jewett 2007:444-445), as stylfiguur aan om hierdie dilemma te verwoord.

Al vraag wat oorbly, is wat presies die argument is wat die denkbeeldige karakter of Paulus hier voer. Dit gaan wel oor die onvermoë van die wet (vgl. 8:3), maar by watter aspek of stadium van Paulus se lewe sluit dit aan? Dit bring ons by die tweede vraag waarmee ons hierdie oorsig begin het, naamlik na watter stadium in Paulus se lewe hier verwys word.

\section{Watter stadium van Paulus se lewe is ter sprake?}

Oor die vraag na watter stadium in Paulus se lewe hier verwys word, is daar nog glad nie konsensus onder geleerdes nie. Daar is basies twee moontlikhede: óf Paulus se bestaan vóór sy bekering, óf ná sy bekering. ${ }^{19}$ Daar is goeie argumente na weerskante toe. Trouens, die keuse tussen die twee moontlikhede is volgens Schreiner (1998:390) so fyn gebalanseer dat 'n keuse na enige kant toe onmoontlik is. Volgens hom is dit nie Paulus se bedoeling om tussen gelowiges en ongelowiges in Romeine 7 te onderskei nie, juis omdat daar waarheidsmomente in albei opsies is. Daarom bied Schreiner (1998:379-392) 'n volledige oorsig oor die argumente na weerskante toe en kom hy tot die slotsom dat die hoofsaak wat Paulus hier probeer beredeneer, die onvermoë van die wet is om geestelike transformasie by die mens te bewerkstellig (vgl. ook Yi 2000:29-30). Mense is vasgevang in die sonde. Tog, soos Romeine 8 aantoon, is mense wat die verlossing in Christus deelagtig geword het, wel in staat om aan die eise van die wet te voldoen deur die krag van die Heilige Gees, al is dit slegs in voorlopige sin. Volgens Schreiner (1998) wil Romeine 7 uiteindelik, soos in die res van die Pauliniese teologie, die dilemma van gelowiges se lewe voorstel, naamlik dat hulle alreeds deel het aan die koninkryk van God, maar nog nie die finale konsummasie daarvan beleef nie.

Dit is egter onseker of Schreiner reg laat geskied aan Paulus se argument in Romeine 7. Hy laat toe dat die algemene teologiese insigte vanuit Paulus se teologie sy eksegese van Romeine 7 oorweldig. Volgens resente eksegese is Paulus hier met 'n unieke argument besig wat onderskei moet word van wat elders wel by Paulus voorkom, maar nie hier die kwessie is nie. Schreiner staan dus bietjie geïsoleerd binne die huidige eksegetiese toneel met sy siening, hoe reg dit ook al in die algemeen vanuit Paulus se totale teologie klink. Die resente eksegese is van mening dat Paulus hier wel oor sy onbekeerde vorige lewe praat (vgl. Schröter 2013:220).

In my aanbieding hieronder gaan die twee interpretasies van watter stadium in Paulus se lewe - vóór of ná sy bekering dus nie as gelyke moontlikhede naas mekaar gestel word nie, maar gaan ek by die huidige (relatiewe) eksegetiese konsensus aansluit. Ek gaan die standpunt beredeneer dat die 'ek' van Romeine 7 outobiografies verstaan moet word (soos bo reeds aangetoon) en dat Paulus na sy onbekeerde bestaan verwys, dit wil sê vóór hy tot geloof gekom het in Jesus as die Messias. Tussendeur sal egter wel standpunte van die ander moontlikheid ingesluit word, soos en wanneer ter sake.

19.'Bekering' by Paulus moenie in die moderne sin van die woord verstaan word nie aangesien Paulus nie na sy 'bekering' opgehou het om Jood te wees nie. Hy het sy
verdere lewe voortgesit as iemand wat steeds glo in die God van Israel, maar nou net as' $n$ volgeling van Jesus die Messias. 


\section{Vooraf opmerkings}

Dit is altyd nuttig om 'n bladsy uit die interpretasiegeskiedenis van 'n Bybelgedeelte te neem voor mens met eie argumente vorendag kom. Ek doen dit nou kortliks ten opsigte van Romeine 7 (vir 'n meer gedetailleerde oorsig van hierdie gedeelte se uitleggeskiedenis kyk Witherington 2004:181-185 en Schröter 2013:199-207.)

Die meeste van die vroeë kerkvaders, onder andere Augustinus, het die standpunt gehuldig dat Paulus in Romeine 7 sy onbekeerde verlede beskryf. In sy stryd teen Pelagius (wat die vrye wil van die mens verkondig het wat deur middel van die navolging van Christus sonde kan oorwin) het Augustinus sy standpunt oor Romeine 7 verander, naamlik dat Paulus sy lewe as Christen beskryf. So het Augustinus vir Pelagius die moontlikheid ontneem om die positiewe wetsaspekte van Romeine 7 (bv. vers 22, 'ek verlustig my in die wet van God ...') op die onbekeerde mens te betrek..$^{20}$ Hierdie standpunt van Augustinus het groot invloed in die Westerse kerk uitgeoefen en is later by die kerkvergaderings van Kartago (Noord-Afrika) in 418 n.C. en Orange (Frankryk) in 529 n.C. vir die Rooms-Katolieke tradisie gekanoniseer. Augustinus het veral die saak van begeerte (concupiscientia) as die belangrikste sonde van Romeine 7 uitgelig (vgl. vers 8).

Wat Augustinus vir die Roomse tradisie gedoen het, het Luther en Calvyn baie eeue later vir die Protestantse tradisie gedoen. Hulle - veral Luther - sluit by Augustinus aan en pas Romeine 7 op die Christen se lewe toe. Luther se slagspreuk is bekend: simul iustus et peccator [die Christen is regverdige sowel as sondaar]. Luther regverdig hierdie siening vanuit die 'ek' se stryd rondom die goeie en die kwade in Romeine 7. Anders as Augustinus het Luther die kernsonde in Romeine 7 nie as begeerte gesien nie, maar as eiegeregtigheid. Hy het dit veral gehad teen die teologie van meriete (werkheiligheid) van die Judaïsme en die Rooms-Katolisisme van sy dag. In albei gevalle, sê Luther, lei dit tot eiegeregtigheid.

In die negentiende en twintigste eeu is en word die Protestantse siening van Romeine 7 steeds deur Luther en Calvyn beïnvloed. Teoloë soos Bultmann, Barth, Cranfield, Käsemann, Barrett (kyk Witherington 2004:184) en Dunn (1988:411-412) volg almal hierdie interpretasielyn.

Dit is eers van die sewentigerjare van die vorige eeu af dat die winde van verandering begin waai het oor die uitleg van Romeine 7 . Dit was as gevolg van 'n groter insig in die Joodse situasie in die eerste eeu na Christus, en gevolglik van Paulus en die wet, asook van die opkoms van 'n uitlegmetode soos retoriese analise in sy toepassing op die Nuwe Testament. Dit het 'n herwaardering van die retoriese karakter van Romeine en van die sosiale situering van

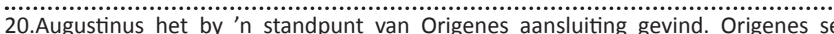
kommentaar is die eerste op Romeine wat vir ons behoue gebly het. Hy het oor die algemeen die vrye wil van die mens voorgestaan, maar het oor Romeine 7 ges dat ons hier die swakke, vleeslike Christen teekom (vgl Schroter 2013:199) wat in die kloue van sy tweede (sondige) natuur vasgevang is. Dis by hierdie gedagte van Origenes dat Augustinus aansluit om die mens in die mag van sonde te tipeer (vgl. Müller 2009:237).
Paulus tot gevolg gehad. Dit het ook veroorsaak dat daar uit die keurslyf van denke waartoe die Protestantse eksegetiese tradisie eksegete gepredisponeer het, gebreek is. Daar is oor die algemeen weer teruggekeer na die vroeë kerkvaders se uitleg van Romeine 7, maar nou vanuit 'n meer verfynde teksanalise.

Met hierdie oorsig as agtergrond kan daar nou in fyner besonderhede gekyk word na die argumente ten gunste van die siening dat Paulus in 7:14-25 na sy verlede voor sy bekering verwys.

\section{Beredenering van die standpunt dat Paulus na sy lewe voor sy bekering verwys}

\section{Argument vanuit struktuur}

Romeine 7:5-6 volg 'n bepaalde patroon: vers 5 vertel van die begeertes van die sonde wat deur die wet uitgelok is en wat tot die dood gelei het. Vers 6 vertel van die vrystelling van die wet sodat die mens in die nuutheid van die Gees kan dien. Romeine 7:7-25 brei die gedagte van 7:5 uit waar sonde en dood domineer vanweë die teenwoordigheid van die wet. Romeine 8:1-17 neem weer die gedagte van 7:6 op waar die lewe van vryheid in die Gees beskryf word. Mens kry dus die volgende patroon (so Schreiner 1998:385):

A Lewe onder die wet: Onbekeerde evaring word beskryf (7:5)

B Lewe in die Gees: Bekeerde ervaring beskryf (7:6)

$\mathrm{A}^{\prime}$ Lewe onder die wet: Uitbreiding (7:7-25)

$\mathrm{B}^{\prime}$ Lewe in die Gees: Uitbreiding (8:1-17)

Hiervolgens is dit duidelik dat 7:7-25 Paulus se lewe beskryf voor sy bekering tot Christus as die Messias.

\section{Die kontras tussen Romeine 7:14-25 en 8:1-17}

Hierdie argument sluit ten nouste aan by die vorige. Die klem val nou egter op die emfatiese vovv van 8:1: 'Daar is dan nou geen veroordeling vir dié in Christus Jesus nie.' Hierdie kontras ${ }^{21}$ is so dramaties in vergelyking met die voorafgaande dat mens beswaarlik kan aanvaar dat die twee ervarings, wat onderskeidelik in 7:14-25 en 8:1-17 beskryf word, dieselfde Christelike ervaring weergee (Schreiner 1998:387). Dit moet eerder gesien word dat 8:1-17' $n$ ander (Christelike) ervaring beskryf as dié van 7:14-25 - laasgenoemde dan die situasie vóór Christus. Voorheen was Paulus onder veroordeling, maar nou is hy in Christus en daarom nie meer onder die oordeel van God nie. 'n Nuwe heilshistoriese situasie het aangebreek: vryheid in Christus en in die Gees (vgl. Burgland 1997:168; Witherington 2004:208-209).

\section{Die klem op die Heilige Gees in 8:1-17}

Nêrens in 7:14-25 word $\pi v \varepsilon v \tilde{\mu} \alpha$ in die sin van die Heilige Gees vermeld nie, terwyl daar 19 keer na Hom verwys

\footnotetext{
21. Met kontras word die hele argument van $7: 7-25$ teenoor 8:1-17 bedoel. Jewett (2007:479) noem byvoorbeeld dat die gevolgtrekking-partikel ő $\rho \alpha$ van 8:1 teruggryp op 7:6 om die draad van die argument dáár op te tel nadat dit deur 7:7-25 onderbreek is (vgl. ook Schreiner 1998:399). Die kontras is dus tussen die ö $\tau \varepsilon$ van 7:5 en die võv van 8:1 (Schmidt 1966:134). Reeds in 7:5-6 is die kontras tussen lewe in die vlees en dié in die Gees beskryf. Eersgenoemde is verder in 7:7-25 uitgebrei, waarmee die lewe in die Gees in 8:1-17 nou weer gekontrasteer word.
} 
word in 8:1-17. In 7:14-25 gaan dit dus oor die 'ek' wat op sy eie die wet probeer uitleef en telkens tot die wrede ontdekking kom dat dit nie kan nie. Daarteenoor handel 8:1-17 oor die persoon wat die inwonende Gees ontvang het en daarom in staat is om die wet van God uit te leef. Romeine 8:1-17 vorm dus die teenpool van 7:14-25. Anders gestel: die vleeslike persoon waarna in 8:5-8 verwys word, vorm die parallel met die persoon in 7:14-25 wat in die greep van sonde en die wet verkeer (vir bg. argument, kyk Schreiner 1998:388).

Hierdie toedrag van sake hang saam met die Joodse verwagting dat die koms van die Gees 'n era van krag en morele vernuwing sal inlui waar gewone gelowiges in staat sal wees om die wet van God uit te leef (vgl. Dunn 1998:417418; Sjöberg 1968:384-385). Volgens 8:1-17 het daardie tyd nou aangebreek. Die eskatologiese tyd is hier, die era van die Messias en die Gees het gekom, die werke van die vlees kan nou doodgemaak word.

Die enigste afleiding wat ' $n$ mens uit bogenoemde kan maak is dat 7:14-25 en 8:1-17 in kontras met mekaar is rondom die ontvangs van die Heilige Gees, al dan nie: 8:1-17, die Christengelowige wat die Gees ontvang het; en 7:14-25, die persoon wat in eie krag die wet probeer uitleef. Twee heilshistoriese eras word so uitgebeeld: die eskatologiese bedeling van die Gees teenoor die ou bedeling van die vlees (vgl. Hays 1996:43-46).

\section{7:14-24 nie tipies van Christelike lewe}

'n Argument wat nóú saamhang met die vorige een is dat voorstanders van die standpunt dat 7:14-24 die nábekeringsituasie beskryf (bv. Cranfield 1985:154-155; Dunn 1988:411-412; Garlington 1990:199-200, 234-235; Wilckens 1980:101-117), 'n probleem het om te verduidelik waarom so 'n haglike prentjie van die Christelike lewe geskets word (vleeslik, verkoop onder die sonde, doen wat jy haat, kan nie die goeie doen nie, ens.) (Schreiner 1998:389-390). Dit is in skrille kontras met byvoorbeeld Romeine 6 wat sê dat diegene in Christus dood is vir die sonde en nie langer slawe van die sonde is nie. Om nie eens van 8:1-17 (behandel onder die vorige hofie) te praat nie. Die prentjie wat in 7:14-24 geteken word, is van 'n totale onvermoë om God se wil te doen, ten spyte van die begeerte om dit te wíl doen. Soos Garlington (1990:234) heel tereg opmerk: Indien 7:14-25 as die stryd van die Christen teen die sonde gesien word, dan is dit uniek in die Pauliniese geskrifte as 'n gedetailleerde beskrywing daarvan. Anders as Garlington, aanvaar ek daarom dat so 'n prentjie eerder tekenend van die voorbekeringservaring is.

\section{Die \&̇yó wat hom in die wet verlustig is nie 'n probleem nie}

Voorstanders van die standpunt dat 7:14-25 die nábekeringsituasie tipeer, wys gewoonlik daarop dat 7:22 nie by die voor-bekeringsituasie inpas nie. Hoe kan 'n ongelowige hom immers verlustig in die wet van God? So-iets pas tog net by die gelowige (vgl. Dunn 1988:394).
As dit oor die ongelowige gegaan het wat in opstand teen God leef, sou hierdie beswaar miskien gewig gedra het. Daar is egter al voorheen daarop gewys dat dit hier oor ' $n$ baie spesifieke situasie gaan, naamlik die wetsgetroue Jood wat hom inderdaad in die wet van God verlustig (Jewett 2007:457, 469-470). Die situasie soos in 7:14-24 beskryf, is tipies van die vrome Jood; trouens van enige persoon wat 'n moreel suiwer lewe probeer leef. Sulke persone verlustig hulle inderdaad in die wet, en dit is presies Paulus se punt. Voor sy bekering tot Christus was hy bekend as 'n yweraar vir die wet (Gal 1:13-14; Fil 3:4-6), en hy prys die Jode ook vir hulle ywer (9:31-32; 10:2). Die probleem is net dat dit hulle niks baat nie, want die geregtigheid van God kan nie deur ywer vir die wet verdien word nie. Daarvoor is die vlees te swak. Die wet stel jou telkens voor jou eie onvermoë en sonde. Die geregtigheid van God kan slegs op grond van God se genade deur die geloof ontvang word.

Romeine 7:22 is dus nie 'n spyker in die doodskis van die standpunt dat Paulus in 7:14-24 sy voor-bekeringsituasie beskryf nie.

\section{Die praesentiese werkwoorde van 7:14-25 is nie ' $n$ probleem nie}

'n Belangrike argument ten gunste van die standpunt dat dit in 7:14-25 oor Paulus se na-bekeringslewe gaan, is die wisseling in werkwoordtye tussen vers 7-13 (in die verlede tyd, wat dan op die vorige onbekeerde lewe van die 'ek' sou dui) en 14-25 (in die teenswoordige tyd, wat op die huidige bekeerde lewe van die ' $\mathrm{ek}^{\prime}$ sou dui).

Dit is egter beswaarlik ' $n$ argument. Eerstens dui die Griekse praesens nie noodwendig die hede aan nie (Schreiner 1998:386). Die gebruik van die sogenaamde historiese praesens is ' $n$ bekende manier om gebeure in die verlede met praesentiese werkwoorde te beskryf. Tweedens, die oorgang tussen 7:13 en 14 word te swak aangedui om te aanvaar dat die argument nou na die bekeerde 'ek' verskuif (vgl. Seifrid 1992:319). Derdens kan 'n mens die oorgang van verlede na teenswoordige tyd tussen 7:7-13 en 14-25 so verduidelik: verse 14-25 beskryf in lewendige terme die toestand of staat van die persoon wat aan sonde verslaaf is. Praesentiese werkwoorde beskryf so 'n toestand die beste. In 7:7-13 beskryf Paulus weer sy verlede in die narratiewe genre, waar die verlede tyd van die werkwoord beter pas.

\section{Na-bekeringsperspektief op die voormalige Joodse bestaan}

Die finale besluit oor watter van die twee sieninge aangaande die stadium van die 'ek' wat in 7:14-25 beskryf word, 'n mens steun, hang dikwels nie van suiwer eksegetiese argumente af nie, maar het te make met die eksegeet se eie hermeneutiesteologiese raamwerk. Wat geniet voorrang: die stryd- of die oorwinningsaspek? Dít gaan in 'n groot mate bepaal watter argumente die meeste indruk maak. Dis presies om hierdie rede dat albei eksegetiese opsies nog aanhang geniet vandag.

Die argumente dat Paulus in 7:14-25 na sy voorbekeringsituasie verwys, maak egter eksegeties die meeste 
sin. Paulus probeer sy vorige lewe so lewendig as moontlik beskryf en maak daarom gebruik van die retoriese tegniek van prosopopoeia om 'n karakter in die eerste persoon en met werkwoorde in die praesens te laat optree. Dit verhoog die dramatiese en emosionele effek van sy beskrywing.

Die vraag is net of die voor-bekeringspersoon so ' $\mathrm{n}$ insig in sy of haar eie situasie kan hê soos hier beskryf word. Veral die vroom Jood wat vreugde vind in die wet van God en hom of haar daarin verlustig. Sal hy of sy kan identifiseer met die prentjie wat Paulus hier skets? Waarskynlik nie. Daarom is geleerdes van mening dat dit nie voldoende is om bloot te sê dat Paulus hier sy voor-bekeringservaring beskryf nie. Dis belangrik om by te voeg dat Paulus dit by wyse van terugskouing doen vanuit sy huidige na-bekeringslewe (vgl. Rosenau 1990:20). Hy kyk met Christelike oë terug op sy vorige lewe (Witherington 2004:195). Dan het mens 20/20 visie. Noudat hy oortuig is dat mens nie die geregtigheid van God kan verdien deur uit te blink in die nakoming van die wet nie, kan hy terugkyk op die futiliteit van sy vorige bestaan en op dié van alle Jode, hoe vroom ook al, wat so 'n lewe probeer voer. Dis nie 'n perspektief wat jy as Jood kan hê nie. So 'n perspektief kan eers verkry word wanneer jy vanuit die geloof in Christus jou vorige lewe in oënskou neem. Dis daarom dat Paulus sulke sterk taal soos in 7:14-24 oor sy vorige lewe kan gebruik, en soos in Filippense 3:8 waar hy sê dat hy alles wat vir hom voorheen van waarde was as $\sigma \kappa v ́ \beta \alpha \lambda \alpha$ [drek, gemors] beskou sodat hy Christus as wins kan verkry. Geen nie-Christen Jood sal met Paulus hieroor saamstem nie; slegs iemand wat dieselfde pad as Paulus geloop het en tot nuwe insigte in Christus gekom het.

Ons moet dus besef dat Paulus besig is met kragtige Christelike retoriek om die evangelie teenoor die Judaïsme van sy dag, soos hy dit voorheen beleef en beoefen het, te stel. Hy is nie daarop uit om 'n objektiewe vergelyking tussen die weg van Christus en die Judaïsme te tref nie. Hy praat vanuit sy subjektiewe ervaring as iemand wat tot die oortuiging gekom het dat die wyse waarop die wet in die Jodedom funksioneer, nie vir die mens geregtigheid by God kan bewerk nie. Paulus redeneer as passievolle apostel vir die saak van Christus. Uiteraard gee hy dus ' $n$ bevooroordeelde evaluering van wat Jood-wees behels waarmee die beoefenaar van die Judaïsme nie sal saamstem nie - nie destyds nie en ook nie vandag nie. Nuwe-Testamentiese gegewens oor die verhouding tussen Christen- en Jood-wees, soos deur die oë van Paulus gesien, is gevolglik nie goeie, ewewigtige godsdiensvergelykende materiaal nie. Dis ideologies gekleur, sterk retories en propagandisties, met ander woorde, sendingmateriaal. Daarmee moet 'n mens vrede maak.

Dit beteken nie dat Paulus ons mislei nie. Vanuit Christelike perspektief het hy ons 'n merkwaardige perspektief gegee nie net op die Jodedom nie, maar ook op die eie aard, uniekheid en die eiendomlike van die Christelike geloof. Sónder hierdie perspektief kan mens maar net sowel enige godsdiens aanhang. Mét hierdie perspektief moet jy 'n keuse maak: vír of téén Christus. Daar is nie 'n middeweg nie.

\section{Implikasie van voor-bekeringsinterpretasie vir'n Christen se daaglikse stryd teen die sonde}

Hierbo is op Luther se verstaan van 7:7-25 gewys, naamlik dat hy dit op die Christen se daaglikse stryd teen die sonde betrek het. Ten spyte daarvan dat die Christen in Christus regverdig voor God is, is ons nooit ontslae van die sonde nie. Die stryd teen die sonde gaan voort en ons struikel en val (sondig) dikwels. Dus is die Christen tegelyk regverdige en sondaar (simul iustus et peccator).

Die vraag is: Indien 7:7-25 nie as tiperend van die Christen se daaglikse stryd teen die sonde verstaan word nie, verdwyn hierdie beginsel dan uit Paulus se teologie en ook uit die Christelike teologie as sodanig? Nee, want die gedagte van ons daaglikse stryd teen die sonde rus nie op 7:7-25 nie, maar word as algemene eienskap van Paulus se teologie gepostuleer vanuit die eksplisiete en implisiete manier waarop hy oor die sonde in gelowiges se lewe handel. Galasiërs 6:1 verwys byvoorbeeld eksplisiet na iemand wat in sonde geval het en wat weer deur die 'geestelike gelowiges' ( $\pi v \varepsilon v \mu \alpha \tau$ เ deernisvolle manier reggehelp moet word. Die hele manier waarop Paulus praat oor die 'vleeslike' Christene (баркикоí) in Korinte wat soos babas in Christus is (1 Kor 3:1-4) en dat hy nie met hulle kon praat soos met 'geestelike gelowiges' ( $\pi v \varepsilon v \mu \alpha \tau$ коí) nie, sny alle gedagtes van morele perfeksie by Paulus by die wortel af. Paulus was maar te bewus van die voortgaande werking van die sonde in gelowiges se lewe. Daarom is hy in sy briewe voortdurend besig om mense te vermaan en aan te moedig om hulle status in Christus uit te leef en nie toe te laat dat sondige praktyke hulle lewe oorwoeker nie (vgl. 6:12-14).

Paulus was egter ook oortuig dat die ou bedeling verby is en die nuwe, eskatologiese bedeling in Christus aangebreek het. Daarom dat hy sulke sterk uitsprake maak dat as jy in Christus is, jy 'n nuwe skepping is (2 Kor 5:17), dat jy dood is vir die sonde (Rom 6), en dat daar geen veroordeling meer is nie (Rom 8:17). Dit is vanuit hierdie uitsprake dat die gedagte van die 'alreeds' en die 'nog nie' as tiperend van Paulus se teologie deur teoloë geformuleer is (vgl. Hays 1996:21; Ridderbos 1973:284). Christene is alreeds deel van die nuwe bedeling en as sodanig vry van die mag van sonde, maar vir sover ons nog deel van die ou bedeling is, het die koninkryk van God nog nie finaal aangebreek nie. Dit is tussen die 'alreeds' en die 'nog nie' dat die Christen se lewe op aarde, waarvan die stryd teen die sonde deel is, gevoer word.

Die Christen kan dus inderdaad as tegelyk regverdige en sondaar ${ }^{22}$ beskryf word. Die punt is net dat dít nie die saak is wat in 7:14-25 aan die orde is nie. Die teksgegewens dui eerder op iets anders. Paulus is hier besig om sy vorige bestaan onder die Mosaïese wet, as verteenwoordiger van Israel, vanuit Christelike perspektief in oënskou te neem. Die argument gaan nie oor sy huidige stryd teen die sonde nie,

22.Ek gebruik hierdie uitdrukking as populêre beskrywing van die Christen se stryd teen die sonde en nie noodwendig as tiperend van Paulus se teologie nie. Dit kan teen die sonde en nie noodwendig as tiperend van Paulus se teologie nie. Dit kan
byvoorbeeld gedebatteer word of Paulus die mens in Christus as 'sondaar' tipeer, juis vanweë die gelowige se korporatiewe verbondenheid aan Christus. 
maar spesifiek oor die heilsbemiddelende funksie van die wet. Ons het aan die begin reeds daarop gewys dat die wet die sentrale argument van Romeine 7 is. Daaroor is sy slotsom dat dít nie die manier is om geregtigheid by God te verwerf nie. Daardie pad het hy geloop en dit is 'n doodloopstraat. Hoewel die wet dus goed en reg en heilig is, het dit nie as wet die vermoë om jou lewe te transformeer nie. Inteendeel, dit laat die sonde net meer word. Selfs al wíl jy dit uit eie krag probeer uitleef, lei dit telkens tot mislukking, valsheid en hoogmoed oor jou eie vermeende geestelike vermoëns. Die eintlike transformerende $\mathrm{krag}$ is die persoonlike verhouding met God deur die geloof en vertroue in Christus, en die werk van die Heilige Gees. Vanuit hierdie bevrydende verhouding kan jy werk maak van die sonde en jou wy aan God. Uiteraard kom die wet dan weer op jou agenda (8:4), maar hierdie keer vanuit die bevryding in Christus en deur die krag van die Heilige Gees.

\section{Implikasie van eksegetiese keuse vir prediking oor Romeine 7:14-25}

Wat mens dikwels aantref in die prediking oor 7:14-25 is dat hierdie teks as 'n tipiese beskrywing van die lewe van die Christen geneem word, met ander woorde, die standpunt dat die Christen se lewe daarin bestaan dat 'n voortdurende innerlike stryd gevoer word teen die sonde. Ons is burgers van twee wêrelde, die ou bedeling van sonde en die nuwe van oorwinning. Dit is die simul iustus et peccator-gedagte. Hierdie preeklyn volg uiteraard die uitlegtradisie dat Paulus in Romeine 7:14-25 as Christen praat, ná sy bekering. Die volgende uittreksel uit 'n preek (Sutherland 2006:ad loc.) illustreer hierdie tradisie:

In our text, Paul is describing his own personal struggle with sin. This is the most dramatic testimony of Paul's struggle with sin. We have little difficulty believing that we struggle with sin or that others like Peter struggled, but Paul somehow seems above it all. This is a misconception, as our theology should remind us, and as Paul's words instruct us. Paul's struggle is a deeply personal struggle, with sin and with his own flesh. It is a war within. It is a war which results from his conversion, a war which did not exist until he was saved.

Die uitleg wat in my bydrae gevolg word, noodsaak egter 'n ander preekroete. Dit moet eerder die neiging by mense beklemtoon om vanuit eie krag 'n lewe te lei wat vir God en medemens aanvaarbaar is, maar dan telkens tot mislukking gedoem is vanweë die onvermoë van die mens om aan God of mensgemaakte standaarde te voldoen. So 'n lewenshouding kan by moreel of godsdienstig sensitiewe nie-Christene manifesteer, maar ook by Christene wat wetties ingestel is en so by godsdienstige wettisisme eindig. Dit is die tipiese self made person-sindroom wat so maklik van ernstig gesinde mense besit kan neem. Dit verteenwoordig die lewenshouding en -styl wat Paulus as yweraar vir die wet van Moses gehad het, ${ }^{23}$ maar wat hy uiteindelik as 'n

23.Allen (2014:106) is van mening dat dit die groot sonde van Paulus (en die Jode van sy tyd) was dat hulle die wet verabsoluteer het. So het hulle in ' Jode van sy tyd) was dat hulle die wet verabsoluteer het. So het hulle in ' wetsfundamentalisme verval en yweraars vir die wet, los van God, geword. Allen (2014:106) stel dit so: '... the trouble becomes that any pursuit of "the good" that puts zeal for the pursuit above the good itself is bound by sin'. futiele poging moes laat vaar ná sy ontmoeting met Christus. As iemand wat die genade van God in Christus ontdek het, kan hy nou terugkyk op hierdie voorheen futiele lewe wat hy nou kan tipeer as: 'Ek, ellendige mens! Wie sal my van hierdie doodsbestaan verlos? Aan God die dank! Hy doen dit deur Jesus Christus ons Here' (7:24-25).

Die voordeel van hierdie eksegetiese keuse is dat die swaartepunt van die argument in Romeine 7 , naamlik die onvermoë om die wet as heilsbemiddelende of transformerende entiteit te onderhou, sentraal gestel word. Dis nie dat die daaglikse stryd teen die sonde of die feit dat ons tegelyk verlostes en sondaars is (die eerste eksegetiese lyn), ontken word nie. Daar word egter gekies vir die standpunt dat dit futiel is om, in ons stryd teen die sonde, die wet as heilsweg te aanvaar. Die wet is nie 'n heilsweg of die transformerende krag in ons lewe nie, maar wel Christus deur die Heilige Gees. Anders gestel: dit is net so 'n gevaarlik om 'n teologie aan te hang wat die innerlike stryd van die Christen teen die sonde ontken as om een voor te staan wat hierdie stryd wil voer met die wet in plaas van die genade van God in Christus. Dit is laasgenoemde eksegetiese lyn wat in die prediking oor 7:14-25 uitgebou moet word.

Hierdie eksegetiese keuse word in die volgende preekuittreksel geillustreer (Sarver 2002:ad loc.):

You can see many examples in society of people's desire to change and be a better person. The self-help books that line many bookstores are evidence of this desire. ... The inability of people to get an appointment at Christian and secular counselors because of demand shows us that there is an abundance of people seeking to change for the better. Sometimes even church attendance is motivated by this longing and is evidence of this inward desire to be a better person.

I bring all this up because Paul, in this passage of Scripture, is talking about people's efforts to be a better person. He is speaking about the desire to live a godly life otherwise known as a holy or sanctified life in Christian circles. He knows about such efforts to be a better person because he has sought to live such a life. He did so with all his willpower in the past. He also knows that despite all his efforts he did not become a better person. His strenuous attempts produced nothing but utter failure and frustration. ... Later in chapter eight of Romans he points to a new way that really results in the kind of changes God and we desire through Jesus Christ and the power of the Holy Spirit. Before we get to the answer to really becoming a better person Paul wants to understand the inability of a person to really change in his or her own power.

To try and be a better person without Jesus would be like Christopher Reeves [former 'Superman' before his accident that left him a quadriplegic - author's own explanation] trying to win the Boston Marathon. He could not because of his condition. You can no more be a better person without Jesus than a man could have a baby. All the efforts in the world will not result in a pregnancy. Paul is saying that we cannot live a good life in our own power because of our condition which is 'unspiritual'.

Met bostaande uiteensetting en preekillustrasies behoort dit duidelik te wees dat daar ' $n$ fundamentele verskil moet wees 
tussen die prediking wat van die eksegetiese opsie uitgaan dat Paulus hier handel oor die futiliteit daarvan om die wet as heilsweg te bewandel, en 'n preek wat die eksegetiese opsie kies dat Paulus hier oor die daaglikse stryd van die Christen teen die sonde handel.

\section{Erkenning}

Hierdie bydrae word met dankbare erkenning opgedra aan my jare lange vriend en kollega, Jan du Rand, by geleentheid van sy 70 ste verjaardag. Om die Skrif ernstig te neem, ook vir die prediking, was nog altyd vir Jan 'n saak van erns. Vandaar die keuse om in hierdie bydrae die twee groot liefdes van sy akademiese lewe - eksegese en prediking - by mekaar uit te bring.

\section{Mededingende belange}

Die outeurs verklaar dat hulle geen finansiële of persoonlike verbintenis het met enige party wat hulle nadelig of voordelig kon beïnvloed het in die skryf van hierdie artikel nie

\section{Literatuurverwysings}

Allen, A.L., 2014, 'Captivity, turning, and renewal: Three liturgical readings of Romans 7:15-8:13', Currents in Theology and Mission 41(2), 102-109.

Bultmann, R., 1967 [1932], 'Römer 7 und die Anthropologie des Paulus', in E. Dinkler (hrsg.), Exegetica, pp. 198-209, Mohr, Paul Siebeck, Tübingen.

Burgland, L.A., 1997, 'Eschatological tension and existential Angst: "now" and "not yet" in Romans 7:14-25 and 1QS11 (Community Rule, Manual of Discipline)', Concordia Theological Quarterly 61(3), 163-176.

Cranfield, C.E.B., 1985, Romans. A shorter commentary, T\&T Clark, Edinburgh.

Deenick, K., 2010, 'Who is the "I" in Romans 7:14-25?', The Reformed Theological Review 69(2), 119-130.

DeSilva, D.A., 2004, An introduction to the New Testament. Contexts, methods and ministry formation, InterVarsity Press, Downers Grove, IL.

Dunn, J.D.G., 1988, Romans 1-8, Word Books, Dallas. (WBC, 38A).

Dunn, J.D.G., 1998, The theology of Paul the apostle, T\&T Clark, Edinburgh.

Du Toit, D.S., 2013, 'Christlicher Glaube als endzeitliche Variante des Glaubens Abrahams', in P-G. Klumbies und D.S. du Toit (Hrsgs.), Paulus - Werk und Wirkung. Festschrift für Andreas Lindemann zum 70. Geburtstag, pp. 325-350, Mohr Siebeck, Tübingen.

Fitzmyer, J., 1993, Romans: A new translation with introduction and commentary, Doubleday, New York. (The Anchor Bible, 33).

Garlington, D.B., 1990, 'Romans 7:14-25 and the creation theology of Paul', Trinity Journal 11(NS), 197-235.

Goodrich, J.K., 2013, 'Sold under Sin: Echoes of Exile in Romans 7.14-25', New Testament Studies 59(4), 476-495. http://dx.doi.org/10.1017/S0028688513000180

Hays, R.B., 1996, The moral vision of the New Testament. A contemporary introduction to New Testament ethics, HarperOne, New York.

Jewett, R., 2007, Romans: A commentary, Fortress, Minneapolis, MN. (Hermeneia).

Käsemann, E., 1980, Commentary on Romans, SCM, London.

Kim, S., 2002, Paul and the new perspective. Second thoughts on the origin of Paul's gospel, Eerdmans, Grand Rapids, MI.
Kümmel, W.G., 1974, Römer 7 und das Bild des Menschen im Neuen Testament. Zwei Studien, Chr Kaiser Verlag, München. (Theologische Bücherei. Neues Testament, Studien,
Band 53).

Lohse, E., 2003, Der Brief an die Römer, 15.Aufl., Vandenhoeck \& Ruprecht, Göttingen. (Meyers kritisch-exegetischer Kommentar über das Neue Testament, Band 4).

Longenecker, R.N., 1971, The ministry and message of Paul, Zondervan, Grand Rapids, MI.

Marshall, I.H., 2004, New Testament theology. Many witnesses, one gospel, InterVarsity Press, Downers Grove, IL.

McDonald, L.M. \& Porter, S.E., 2000, Early Christianity and its sacred literature, Hendrickson, Peabody.

Moo, D.J., 1996, The epistle to the Romans, Eerdmans, Grand Rapids, MI.

Müller, J., 2009, 'Willensschwäche und innerer Mensch in Röm 7 und bei Origenes', Zeitschrift für neutestamentliche Wissenschaft 100(2), 223-246. http://dx.doi. org/10.1515/ZNTW.2009.0012

Newman, B.M. \& Nida, E.A., 1973, A translator's handbook on Paul's Letter to the Romans, United Bible Societies, Stuttgart. (Helps for translators, XIV).

Reichert, A., 2009, 'Literarische Analyse von Römer 7,7-25A', in U. Schnelle (ed.), The letter to the Romans, pp. 297-325, Peeters, Leuven. (Bibliotheca Ephemeridum Lovaniensium CCCXXVI).

Ridderbos, H., 1959, Aan de Romeinen, Kok, Kampen. (Commentaar op het Nieuwe Testament).

Ridderbos, H., 1973, Paulus. Ontwerp van zijn theologie, Kok, Kampen.

Rosenau, H., 1990, 'Der Mensch zwischen Wollen und Können. Theologische Reflexionen im Anschluß an Röm 7,14-25', Theologie und Philosophie 65(1), 1-30.

Sanders, E.P., 1977, Paul and Palestinian Judaism, SCM, London.

Sarver, L., 2002, 'Changing for the better', viewed 9 January 2015, from http://www. sermoncentral.com/sermons/changing-for-the-better-larry-sarver-sermon-oncharacter-45608.asp.

Schlier, H., 1979, Der Römerbrief, 2.Aufl., Herder, Freiburg. (Herders theologischer Kommentar zum Neuen Testament).

Schmidt, H.W., 1966, Der Brief des Paulus an die Römer, Evangelische Verlagsanstalt, Berlin. (Theologischer Handkommentar zum Neuen Testament, 6).

Schreiner, T.R., 1998, Romans, Baker Academic, Grand Rapids, MI. (Baker Exegetical Commentary on the New Testament).

Schreiner, T.R., 2009, 'An old perspective on the new perspective', Concordia Journal Spring, 140-155.

Schröter, J., 2013, 'Der Mensch zwischen Wollen und Tun. Erwägungen zu Römer 7 im Licht der "New Perspective on Paul"', in P-G. Klumbies und D.S du Toit 7 im Licht der "New Perspective on Paul", in P-G. Klumbies und D.S. du Toit (Hrsgs.), Paulus - Werk und Wirkung. Festschrift für $A$
Geburtstag, pp. 195-224, Mohr Siebeck, Tübingen.

Seifrid, M.A., 1992, 'The Subject of Rom 7:14-25', Novum Testamentum 34(4), 313-333. http://dx.doi.org/10.1163/156853692X00078

Sjöberg, E., 1968, 's.v. $\pi v \varepsilon v ̃ \mu \alpha$ ', in G. Kittel \& G. Friedrich (eds.), Theological Dictionary of the New Testament (TDNT), vol. 6, Eerdmans, Grand Rapids, MI.

Stowers, S.K., 1981, The diatribe and Paul's letter to the Romans, SBL Press, Williston, VT. (SBL Dissertation Series, 57).

Stowers, S.K., 1997, A rereading of Romans. Justice, Jews, and gentiles, Yale University Press, Ann Arbor, Ml.

Stuhlmacher, P., 1994, Paul's letter to the Romans. A commentary, Westminster/John Knox Press, Louisville.

Sutherland, Ted, 2006. 'The thrill of victory or the agony of defeat?', viewed 9 January 2015, from http://www.sermoncentral.com/sermons/the-thrillof-victory-or-the-agony-of-defeat-ted-sutherland-sermon-on-growth-inof-victory-or-the-
christ-89131.asp

Wilckens, U., 1980, Der Brief an die Römer, Benziger Verlag, Zürich. (Evangelisch Katholischer Kommentar zum Neuen Testament, VI/2).

Witherington, B., 2004, Paul's letter to the Romans: A socio-rhetorical commentary, Eerdmans, Grand Rapids, MI.

Yi, Z.G., 2000, 'Simul Justus et Peccator? A closer look at the "ego" of Romans 7 14-25', viewed 2 January 2015, from http://knowledge.e.southern.edu/ senior_research/79 